Lestari, R., \& Fajar, M. (2020). Social support and self-esteem in people with physical disabilities. Indigenous: Jurnal Ilmiah Psikologi, 5(2). 207-217. doi: https://doi.org/10.23917/indigenous. v5i2.11408

\title{
Social Support and Self-Esteem in People with Physical Disabilities
}

\author{
Rini Lestari ${ }^{1}$, Maharani Fajar ${ }^{2}$ \\ Fakultas Psikologi, Universitas Muhammadiyah Surakarta ${ }^{1,2}$ \\ rini.lestari@ums.ac.id', maharanifajar59@gmail.com²
}

\begin{abstract}
Self-esteem is an important individual factor because it determines personality and influences human health. One factor that affects self-esteem is social support. The purpose was to examine the relationship between social support and self-esteem in people with physical disabilities. The hypothesis was there was a positive relationship between social support and self-esteem in people with physical disabilities. It was quantitative research that involved social support and self-esteem. The sampling technique used was purposive sampling. The subject was 103 people with physical or innate disabilities (accidents, illness), 18 -35 years old, and participate in social rehabilitation programs. The instruments were the social support scale and the self-esteem scale. The data analysis technique was regression analysis. The result was social support has a positive relationship with self-esteem in people with physical disabilities. Social support contributed an amount of $47.5 \%$ for self-esteem. People with physical disabilities had medium social support and self-esteem. The study implies that the social rehabilitation center needs to optimize social support in the form of emotional support, information, instrumentals, and appreciation because it plays a role in shaping the self-esteem of people with physical disabilities.
\end{abstract}

Keywords: social support; self-esteem; people with physical disabilities

\section{INTRODUCTION}

Currently, the number of people with physical disabilities is quite large with $10 \%$ of the world's population suffering from various disabilities such as physical, mental, and social disabilities. Meanwhile, $80 \%$ of people with disabilities are found in developing countries (Setareh Forouzan et al., 2013). WHO announces that $15 \%$ of the world's population has physical disabilities in 2018, \pm 100 -200 million people of \pm 13 years, and over suffer physical disabilities, meaning that more than 1 billion people in the world live with physical disabilities. Meanwhile, in 2018, Indonesia had $10.2 \%$ of children of 5-17 years and $44 \%$ of $18-59$ years experiencing disabilities (Ministry of Health, 2018). A large number of people with disabilities in Indonesia requires attention from the government to deal with problems often experienced by people with disabilities in general, including people with physical disabilities.

Disability covers a wide spectrum of chronic conditions that limit mobility or sensory, mental, learning, and emotional functions (Rand \& Harrell, 2009). While Leonardi et al. (2006) define disability as a difficulty in body, person, or social function that limits a person's ability to develop. There are four categories of people with disabilities; physical, mental, intellectual, and sensory (Indonesia Law, 2016). People with physical disabilities are also referred to as crippled, 
physically disabled, physically handicapped - a person who suffers orthopedic, body, and physical disabilities that overburden normal body functions (Merdiasi, 2017; Misbach, 2012). Physical disability can be experienced by a person from congenital or non-congenital (accident, disease).

People with physical disabilities often receive negative treatment such as being labeled based on their physical appearance and lack of accessibility in other aspects of life as what has been received by normal people (Lusli, 2010). People with physical disabilities are also very vulnerable to mental disorders which can reduce their mental health (Turner et al., 2006). Moreover, people with physical disabilities have a greater risk of becoming victims of crime (Yun et al., 2015). It may occur as people with physical disabilities cannot protect themselves from crime (Petersilia, 2001). Compared to other disabilities, physical disability characteristics can be observed so that it is more at risk, especially in children and adolescents (Robinson, 2006). Dawkins (Yun et al., 2015) reports that $30 \%$ of people with physical disabilities have been victims of crime on a regular basis.

Apart from physical problems, people with physical disabilities also often experience social and psychological problems. Research shows that people with physical disabilities are considered dependent, incompetent, lack control, unproductive, ill, burdensome, unattractive, hypersensitive, helpless, passive, and childish (Blockmans, 2015). For this reason, the government provides social rehabilitation centers, one of which is the Social Rehabilitation Center of People with Physical Disabilities (Balai Besar Rehabilitasi Sosial Penyandang Disabilitas Fisik/BBRSPDF) which provides services, rehabilitation, resocialization, and extensive guidance for people with physical disabilities. This social rehabilitation center aims to improve the social function, physical, psychological, spiritual capabilities, and responsibilities of people with physical disabilities as part of society. They are given education and various skills to live in the community. However, different physical conditions still give serious psychological effects and other negative feelings. A survey conducted by Martiani (2014) probed that 78 persons with physical disabilities in BBRSPDF showed that $60.26 \%$ still valued themselves from a negative perspective. Sulaeman (Tentama, 2014) also found that people with physical disabilities still often condemn themselves and like to hurt themselves since they cannot accept their imperfection. People with physical disabilities also often feel ashamed, anxious, incapable, unfortunate, miserable, inattentive, and meaningless. These conditions indicate that their self-esteem tends to be low. Self-esteem determines personality and affects the human health state (Tahir et al., 2015).

Self-esteem is correlated to individual perceptions, feelings, and appreciation for themselves based on realistic perception (Schiraldi, 2007). Realistic means that an individual is dealing with the truth, is accurately and legitimately aware of their strengths and weaknesses, while appreciation shows that the individual has positive feelings. Self-esteem develops in response to life events. When individuals reflect on achievements, self-esteem will increase but if it focuses on failure, it will lower self-esteem (Branscombe \& Baron, 2016).

According to Coopersmith (Amirazodi \& Amirazodi, 2011), self-esteem has four aspects, comprising significance, power, competence, and virtue. Significant is obtained due to affection, acceptance, and attention. Power occurs when an individual can control another individual. Competence happens when an individual succeeds in accomplishing achievements and goals. Virtue emerges when an individual is able to follow the rules that apply in the environment.

Self-esteem is influenced by several factors, including how important it is for others to perceive an individual, the treatment received from others, gender, feedback, parental care (Branscombe $\&$ Baron, 2016), social acceptance (Wagner et al., 2018), level of parental warmth and support (Harris et al., 2017; Orth, 2018), the quality of social relationship (Wagner et al., 2015), and social support (Branscombe \& Baron, 2016). 
Social support plays a vital role in shaping self-esteem (Harris \& Orth, 2019). Social support is the exchange of resources between at least two parties, between the giver and the recipient to improve the welfare of the recipient (Ji et al., 2019). Social support aims to share, exchange information, support emotions, and experiences (Krause, 2003). Social support can take the form of verbal and nonverbal behavior to help others in need (Burleson, 2009).

Social support is in the form of real, emotional, and information support from family members, peers, and significant others (Burleson, 2009). According to Reevyl \& Maslach (Ikiz \& Cakar, 2010), social support can also be provided in the form of instrumental and financial. In addition to emotional support, information, and instrumental support, another support is appreciation (Sarafino \& Smith, 2014). Emotional support is attention, caring, and empathy to create a sense of security and comfort. Instrumental support is direct assistance to a person facing a problem. Support information is information, advice, or suggestions to solve the problem. Appreciation support is giving appreciation to individuals.

Social support has a positive effect on psychosocial functioning, independence, quality of life, health status, and behavior (Brunelli et al., 2016). Those who get social support can also increase their sense of security, general psychological adaptation (Hill et al., 2004), self-esteem (Teoh, 2010), quality of life and reduce depression (Bélanger et al., 2016), stress and emotional problems (Tahir et al., 2015).

Social support has a significant role in improving mental health in people with physical disabilities (Setareh Forouzan et al., 2013). The social environment has an enormous influence on their daily activities. Social contact will allow them to feel a variety of supports from their surroundings. Social contact can also improve the psychological condition of people with physical disabilities to be more positive and strong in dealing with problems so that they possess good selfesteem. They will value for they do not have hands, feet, and imperfect body is a gift from God and there will be a better plan from God. They will also find it easier to face a problem in their life. When facing problems and failures, they will face it with a tranquil heart because there are people who will loyally support them. Meanwhile, those with low self-esteem feel that they will only cause problems for their parents and their surroundings (Triwahyuningsih, 2017). Therefore, individuals need to maintain their self-esteem by engaging in social relationships to obtain social support (Tahir et al., 2015).

Individuals need social support from their surroundings. When experiencing problems, an individual will need the help of a trustworthy person such as friends or family to provide solutions for their problems. Social supports in the form of emotional support, information, instrumentals, and appreciation from the social environment are required by people with physical disabilities to increase self-esteem (Tahir et al., 2015). For people with physical disabilities, high self-esteem is influential so that they can act better and not feel inferior when communicating with their surroundings though they have physical imperfections.

The Republic of Indonesia according to Pancasila highly respects people with physical disabilities. The government has regulated policies related to the welfare of people with physical disabilities in order to achieve independence and an equal degree in all aspects of life (Indonesia Law, 2016). To achieve these desires, people with physical disabilities need emotional, information, instrumental, and appreciation support from their social environment so that awareness of selfesteem as fellow human beings with equal status before the laws of the Republic of Indonesia can be improved.

Research on social support and self-esteem has been carried out on various subjects, however, this research focuses on people with physical disabilities in the social rehabilitation 
program at BBRSPDF Surakarta. Therefore, this study aims to examine the relationship between social support and self-esteem in people with physical disabilities. The hypothesis is that there is a positive relationship between social support and self-esteem in people with physical disabilities.

This research brings advantages for the development of psychological science on the relationship between social support and self-esteem and also an understanding of the role of social support in shaping self-esteem in people with physical disabilities. For the social rehabilitation center, the results of this study can provide important information about social support that has an influential role in the development of self-esteem and help developing work programs that are suitable for the conditions of people with physical disabilities.

\section{METHOD}

This research is a quantitative correlational study involving social support as the independent variable and self-esteem as the dependent variable. This research was conducted at BBRSPDF Surakarta. The population of this study were people with congenital or non-congenital physical disabilities (accidents, disease), 18-35 years, and attended the social rehabilitation program at BBRSPDF Surakarta. The sampling technique used is purposive sampling, which is determining the sample based on certain criteria and characteristics that have been predetermined by the researcher. Based on the sampling technique, the samples of this study were people with congenital or noncongenital physical disabilities (accidents, disease), 18-35 years (average age $=25.3$ years, $\mathrm{SD}=$ 2.09), participated in the social rehabilitation program with a total of 103 people.

Table 1.

Subject Distribution

\begin{tabular}{llcc}
\hline & \multicolumn{1}{c}{ Criteria } & Number & $\%$ \\
\hline Sex & Male & 76 & 74 \\
& Female & 27 & 26 \\
\hline Level of education & Elementary & 9 & 9 \\
& Junior High & 26 & 25 \\
& Senior High & 68 & 66 \\
\hline \multirow{2}{*}{ Type of Physical Disability } & Congenital & 56 & 54 \\
& Non-congenital & 47 & 46 \\
\hline
\end{tabular}

To obtain research data, social support scale and a self-esteem scale were administered. The social support scale was used to measure social support, which consists of emotional, informational, instrumental, and appreciation supports (Sarafino \& Smith, 2014). Social support scale consists of 17 items containing a validity of $0.475-0.875$ and the Cronbach reliability coefficient $\alpha=0.800$. The self-esteem scale was used to measure self-esteem and consisted of significant, power, competence, and virtue aspects. This scale consists of 21 items with a validity of $0.500-0.876$ and the Cronbach reliability coefficient $\alpha=0.817$. All scales used have a reliability coefficient above 0.80 , indicating a high internal consistency (Weels \& Wollack, in Azwar, 2018). The alternatives on the scale are Not Very Appropriate (NVA), Not Appropriate (NA), Appropriate (A), Very Appropriate (VA).

The data analysis used is regression analysis to examine the relationship between social support and self-esteem. 


\section{RESULTS AND DISCUSSION}

To examine the hypothesis proposed by researchers that there is a positive relationship between social support and self-esteem in people with physical disabilities, a statistical analysis was performed. The results of the analysis are shown in Table 2.

Table 2.

Results of analysis

\begin{tabular}{cccc}
\hline Variable & Correlation & Effective Contribution & Correlation Interpretation \\
\hline Social support and self-esteem & $.689^{* *}$ & $47.5 \%$ & Strong \\
\hline
\end{tabular}

Based on statistical calculations, the correlation value is $0.689 ; p=0.000$. It means that there was a very significant positive relationship between social support and self-esteem in people with physical disabilities so that it could prove the hypothesis proposed by researchers. The effective contribution of the social support variable to self-esteem is $47.5 \%$, thus $52.5 \%$ of self-esteem is influenced by other variables.

The correlation between social support and self-esteem variables is 0.689 , which is in the strong category (Sujarweni, 2014). It also supports previous studies that show social support is positively correlated with self-esteem (Ikiza \& Cakarb, 2010; Ji et al., 2019; Tam et al., 2011; Teoh, 2010). Social support in the form of emotional, instrumental, information, and appreciation supports will create a more positive affective condition in people with physical disabilities. It will increase their self-esteem because self-esteem is related to how individuals perceive, feel, and respect themselves realistically (Schiraldi, 2007). If individuals feel the attention, affection, appreciation, and information they need from others, it will make them feel accepted and recognized by others. Social recognition and acceptance are entailed to develop better self-esteem (Wagner et al., 2018). On the other hand, when individuals do not get proper attention, affection, appreciation, and required information, it will make them perceive and feel negative affective conditions so that it can lower their self-esteem. Thus, social support plays an important role in creating and increasing one's self-esteem (Harris \& Orth, 2019).

Social support consists of emotional, information, instrumentals, and appreciation support (Sarafino \& Smith, 2014). Emotional supports are in the form of attention, caring, and empathy to create a sense of security and comfort (Sarafino \& Smith, 2014). People with physical disabilities received attention, guidance, and positive reception from the social rehabilitation center so that they provided a sense of security. Attention and empathy were also obtained from friends, instructors, resident leaders, and social workers in the rehabilitation center. People with physical disabilities who lived far away and were separated from their families felt like families living together and could support and help each other in joy and sorrow. Family and close friends function as direct sources of social support and play a role in the socialization process (Tahir et al., 2015). Huurre (Tahir et al., 2015) states that self-esteem will be higher when support from family and friends are obtained. Other supports were also obtained from the government, which was shown by better access to education, health, politics, technology, information, communication, and job opportunities in the formal and informal sectors. It convinced people with physical disabilities to enjoy their rights without discrimination and helped them feel the positive impact that they were taken care of and accepted by the social environment. Social acceptance will increase self-esteem (Wagner et al., 2018). 
Social support is also obtained from information support, which is the support that can be provided in the form of information, advice, or suggestions to solve problems (Sarafino \& Smith, 2014). In this research, the social rehabilitation center always provided advice and suggestions for the sake of people with physical disabilities. Likewise, when they experienced various problems, they could consult social workers or psychologists. Up to date information on various services and guidance, programs was also regularly provided to people with physical disabilities. Correspondingly, information on people with disabilities working in government and private institutions had also been repeatedly informed as an example and motivation. They could also share experiences and information among friends. The results show that sharing, discussing, and exchanging information with friends can be a source of social support and can increase self-esteem (Carter et al., 2011).

Social support in the form of instrumental support is real and direct support provided when individuals need it (Sarafino \& Smith, 2014). In this case, people with physical disabilities received free education, skills, and physical needs available in the social rehabilitation center. The skills offered ranged from photography, workshop, carpentry, computers, sewing, cooking, and beauty. When they graduated, they also earned working equipment as their initial capital, such as cameras, sewing machines, and beauty equipment. The social rehabilitation centers also provided internship opportunities at government and private institutions to increase their self-esteem and self-confidence. Facilities in center/government, education, clothing, shelter, and work equipment are forms of real support and necessities for people with disabilities to work and earn a living. It is following the conditions of people with physical disabilities who were majorly adults, whose one of the development tasks is to work and be economically independent. At the age of $18-35$ or adult category, they need real instrumental support for working capital that is suitable for their development stage (Santrock, 2011). They were also more realistic about their current needs. They understood and realized that not all people with physical disabilities had the access to free facilities. These experiences and opportunities could lead to positive feelings to help increase their self-esteem.

Appreciation support was obtained from friends, resident leaders, managers, social workers, and instructors. People with physical disabilities lived with those with the same disability so they felt the same way and respected one another. While living in the social rehabilitation center, they also sensed that they received good treatment and appreciation from instructors, social workers, resident leaders, and managers and were not ridiculed regardless of their physical conditions. When they made mistakes during education and training, instructors and social workers also appreciated every effort made and provided motivation that they did better. It is different from the results of previous research showing that people with physical disabilities generally received negative treatment and were labeled based on their physical appearance (Lusli, 2010). People with physical disabilities also received appreciation support from the government with affirmative programs in the form of disability cards, individual assistance, social assistance, and self-reliance This opportunity strengthened the belief of people with physical disabilities that they had received enough appreciation to increase their self-esteem.

Generally, the effective contribution of social support to self-esteem is $47.5 \%$, so there are $52.5 \%$ of other variables that influenced self-esteem internally and externally. The factors affecting self-esteem are the capacity to love, rational thinking, making good decisions, the body condition, including appearance, vitality, health, mood, performance, expertise level, control over events (Schiraldi, 2007), personality traits (Amirazodi \& Amirazodi, 2011), and mindfulness (Pepping et al., 2013). As for external the factors influencing self-esteem are demographic conditions (economic status, gender, race, age), respect, popularity (Schiraldi, 2007), feedback from significant people, disputes and family problems (Mann et al., 2004), gender equality and cultural values (Bleidorn 
et al., 2016), treatment from others (Branscombe \& Baron, 2016), social acceptance (Wagner et al., 2018), level of parental warmth and support (Harris et al., 2017; Orth, 2018), the quality of social relationships (Wagner et al., 2015), and social support (Branscombe \& Baron, 2016; Ikiza \& Cakarb, 2010; Ji et al., 2019; Tam et al., 2011; Teoh, 2010).

Table 3.

Social Support Categories

\begin{tabular}{cccc}
\hline Category & Frequency & Percentage & Information \\
\hline Very low & 6 & $6 \%$ & \\
Low & 20 & $19 \%$ & Moderate category \\
Moderate & 48 & $47 \%$ & \\
High & 26 & $25 \%$ & \\
Very high & 3 & $3 \%$ & \\
\hline
\end{tabular}

Social support has a hypothetical mean of 42.5 and an empirical mean of 53.78 , thus social support for people with physical disabilities is in the moderate category. Overall, the social support received by persons with physical disabilities is as shown in Table 3. The moderate category of social support means that the social support received by persons with physical disabilities is not maximum even though various efforts have been made by the government and the social rehabilitation center. Social support needs to be improved because it is important to increase self-esteem (Branscombe \& Baron, 2016). According to Allen \& Finkelstein (Tahir et al., 2015), social support needs to involve family, closest friends, and communities who are directly connected to people with physical disabilities because significant people, family, and friends are a source of social support which is essential for the development of self-esteem. When living in a social rehabilitation center, friends, instructors, managers, resident leaders are the closest to people with physical disabilities.

Table 4.

Self-Esteem Categories

\begin{tabular}{cccc}
\hline Category & Frequency & Percentage & Information \\
\hline Very low & 10 & $10 \%$ & \\
Low & 21 & $20 \%$ & Moderate Category \\
Moderate & 49 & $48 \%$ & \\
High & 23 & $22 \%$ & \\
Very high & 0 & $0 \%$ & \\
\hline
\end{tabular}

Self-esteem has a hypothetical mean of 52.5 and an empirical mean of 61.48 , thus the selfesteem of people with physical disabilities is in the moderate category. Overall, the self-esteem of people with physical disabilities is shown in Table 4. Self-esteem is classified as moderate because physical condition remains a major concern. People with physical disabilities are more likely to compare their physical with others in the first meeting and are sometimes doubt about others' acceptance because of their imperfection. Numerous studies have also identified that the most important components and major predictors of self-esteem are social acceptance and physical appearance in men and women of all ages (Shapka \& Keating, 2005).

The self-esteem of people with physical disabilities still needs to be improved because it is a measure of a healthy personality (Ikiza \& Cakarb, 2010). Self-esteem is also very important 
for health, problem-solving ability, survival, and health (Rosenberg in Schiraldi, 2007), working hard motivation, increasing welfare, happiness, adjustment, success, satisfaction, and academic achievement (Schiraldi, 2007), increasing performance, personal relationships, health, and a healthy lifestyle, and marital satisfaction (Homaei et al., 2016). Those with low self-esteem are more likely to experience depression, anxiety, poor social functioning, risky behavior, eating disorders (Mann et al., 2004), anxiety, anger, chronic pain, decreased immunity, isolation, and various problematic physical and psychological symptoms (Schiraldi, 2007).

\section{CONCLUSION}

People with physical disabilities experienced various physical, social, and psychological problems. One of the psychological problems they experienced is low self-esteem. Self-esteem can shape identity and influence all aspects of life. This study proves that social support has a positive relationship with self-esteem in people with physical disabilities. These findings also strengthen previous researches with a wide variety of research subjects. Social support made an effective contribution of $47.5 \%$ to self-esteem. Thus there are still $52.5 \%$ of other variables influencing self-esteem such as the capacity to love, rational thinking, good decision making, body condition, personality, demographic conditions, family relationships, popularity, parenting models, social environment, academic achievement, social status, feedback from significant people, and cultural values.

Social support and self-esteem in people with physical disabilities are in the moderate category. Therefore, self-esteem still needs improvement by increasing social support, in the form of emotional, information, instrumental, and appreciation supports. It is because social support has a big role in creating the self-esteem of people with physical disabilities. The formation of self-esteem starts from individual interactions with the assistance of social support coming from their social environments, such as family, friends, instructors, resident leaders, social workers, managers, and community.

The drawback of this study is that the sampling was not carried out randomly so that the results of the study cannot be generalized to a wider range of similar subjects. It denotes that the results of this study only apply to subjects with physical disabilities in BBRSPDF Surakarta. However, the results of this study can provide important information about the conditions of social support and self-esteem in people with physical disabilities. The results of this research can also be applied to the rehabilitation center to develop programs in order to increase social support and self-esteem in people with physical disabilities. The social rehabilitation center can further optimize the social support provided to people with physical disabilities because social support plays an important role in the self-esteem development in people with physical disabilities.

\section{REFERENCES}

Amirazodi, F., \& Amirazodi, M. (2011). Personality traits and Self-esteem. Procedia - Social and Behavioral Sciences, 29, 713-716. https://doi.org/10.1016/j.sbspro.2011.11.296

Azwar, S. (2018). Reliability and validity (ed.4). Yogyakarta : Pustaka Pelajar.

Bélanger, E., Ahmed, T., Vafaei, A., Curcio, C. L., Phillips, S. P., \& Zunzunegui, M. V. (2016). Sources of social support associated with health and quality of life: a cross-sectional study 
among Canadian and Latin American older adults. BMJ Open, 6(6), 1-10. https://doi. org/10.1136/bmjopen-2016-011503

Bleidorn, W., Arslan, R. C., Denissen, J. J. A., Rentfrow, P. J., Gebauer, J. E., Potter, J., \& Gosling, S. D. (2016). Age and gender differences in self-esteem-A cross-cultural window. Journal of Personality and Social Psychology, 111(3), 396-410. https://doi.org/10.1037/pspp0000078

Blockmans, I. G. E. (2015). "Not wishing to be the white rhino in the crowd." Journal of Language and Social Psychology, 34(2), 158-180. https://doi.org/10.1177/0261927X14548071

Branscombe, N. R., \& Baron, R. A. (2016). Social psychology (ed.14). England, UK: Pearson.

Brunelli, A. A., Murphy, G. C., \& Athanasou, J. A. (2016). Effectiveness of social support group interventions for psychosocial outcomes: A meta-analytic review. The Australian Journal of Rehabilitation Counselling, 22(2), 104-127. https://doi.org/10.1017/jrc.2016.9

Burleson, B. R. (2009). Understanding the outcomes of supportive communication: A dualprocess approach. Journal of Social and Personal Relationships, 26(1), 21-38. https://doi. org/10.1177/0265407509105519

Carter, E. W., Moss, C. K., Hoffman, A., Chung, Y.C., \& Sisco, L. (2011). Efficacy and social validity of peer support arrangements for adolescents with disabilities. Exceptional Children, 78(1), 107-125. https://doi.org/10.1177/001440291107800107

Harris, M. A., Donnellan, M. B., Guo, J., McAdams, D. P., Garnier-Villarreal, M., \& Trzesniewski, K. H. (2017). Parental co-construction of 5- to 13-year-olds' Global Self-esteem through reminiscing about past events. Child Development, 88(6), 1810-1822. https://doi. org/10.1111/cdev. 12944

Harris, M. A., \& Orth, U. (2019). The link between self-esteem and social relationships: A metaanalysis of longitudinal studies. Journal of Personality and Social Psychology. Advance online publication. https://doi.org/10.1037/pspp0000265

Hill, W., Schillo, L., \& Weinert, C. (2004). Effect of a computer-based intervention on social Support for chronically III rural women. Rehabilitation Nursing, 29(5), 169-173. https:// doi.org/10.1002/j.2048-7940.2004.tb00340.x

Homaei, R., Bozorgi, Z. D., Ghahfarokhi, M. S. M., \& Hosseinpour, S. (2016). Relationship between optimism, religiosity and self-esteem with marital satisfaction and life satisfaction. International Education Studies, 9(6), 53. https://doi.org/10.5539/ies.v9n6p53

Ikiza, F. E., \& Cakarb, F. S. (2010). Perceived social support and self-esteem in adolescence. Procedia - Social and Behavioral Sciences, 5, 2338-2342. https://doi.org/10.1016/j. sbspro.2010.07.460

Ji, Y., Rana, C., Shi, C., \& Zhong, Y. (2019). Self-esteem mediates the relationships between social support, subjective well-being, and perceived discrimination in chinese people with physical disability. Frontiers in Psychology, 10, 1-7. https://doi.org/10.3389/fpsyg.2019.02230

Krause, M. (2003). The transformation of social representations of chronic disease in a self-help group. Journal of Health Psychology, 8(5), 599-615. https://doi. 
org/10.1177\%2F 13591053030085010

Leonardi, M., Bickenbach, J., Ustun, T. B., Kostanjsek, N., \& Chatterji, S. (2006). The definition of disability: what is in a name? The Lancet, 368(9543), 1219-1221. https://doi.org/10.1016/ S0140-6736(06)69498-1

Lusli. (2010). Ruang demokrasi bagi warga difabel dengan kecacatan. Dalam Jurnal perempuan, 65: mencari ruang untuk difabel (pp. 67-75). Jakarta Selatan: Yayasan Jurnal Perempuan.

Mann, M., Hosman, C. M. H., Schaalma, H. P., \& De Vries, N. K. (2004). Self-esteem in a broad-spectrum approach for mental health promotion. Health Education Research, 19(4), 357-372. https://doi.org/10.1093/her/cyg041

Martiani. (2014). Kasus nonpsikotik di BBRSBD Prof. Dr. Soeharso Surakarta. Laporan praktek kerja profesi psikologi. Surakarta: Magister Psikologi Profesi Universitas Muhammadiyah Surakarta.

Merdiasi, D. (2017). Gambaran tuna daksa yang bekerja. Noetic Psychology, 3(2), 60-81.

Misbach, D. (2012). Seluk-beluk tunadaksa \& strategi pembelajarannya. Yogyakarta : Javalitera.

Orth, U. (2018). The family environment in early childhood has a long-term effect on self-esteem: A longitudinal study from birth to age 27 years. Journal of Personality and Social Psychology, 114(4), 637-655. https://doi.org/10.1037/pspp0000143

Pepping, C. A., O’Donovan, A., \& Davis, P. J. (2013). The positive effects of mindfulness on selfesteem. Journal of Positive Psychology, 8(5), 376-386. https://doi.org/10.1080/17439760. 2013.807353

Petersilia, J. R. (2001). Crime victims with developmental disabilities: A review essay. Criminal Justice and Behavior, 28(6), 655-694.

Rand, M., \& Harrell, E. (2009). National crime victimization survey: Crime against people with disabilities. Washington, DC: Office of Justice Programs, US Department of Justice.

Robinson, S. (2006). Victimization of obese adolescents. The Journal of School Nursing, 22(4), 201-206. https:// https://doi.org/10.1177/10598405050220040301

Santrock, J. W. (2011). Life span development (Perkembangan masa hidup) (ed.13). Jakarta : Penerbit Erlangga.

Sarafino, E. P., \& Smith, T. W. (2014). Health psychology: Biopsychosocial interactions. New York : John Wiley \& Sons.

Schiraldi, G.R. (2007). 10 simple solutions for building self-esteem: How to end self-doubt, gain confidence, \& create a positive self-image. Oakland, CA: New Harbinger Publications.

Setareh Forouzan, A., Mahmoodi, A., Jorjoran Shushtari, Z. J., Salimi, Y., Sajjadi, H., \& Mahmoodi, Z. (2013). Perceived social support among people with physical disability. Iranian Red Crescent Medical Journal, 15(8), 663-667. https://doi.org/10.5812/ircmj. 12500

Shapka, J. D., \& Keating, D. P. (2005). Structure and change in self-concept during adolescence. Canadian Journal of Behavioural Science, 37(2), 83-96. https://doi.org/10.1037/h0087247 
Sujarweni, V. W. (2015). SPSS untuk penelitian. Yogyakarta: Pustaka Baru Press.

Tahir, W. B., Inam, A., \& Raana, T. (2015). Relationship between social support and self-esteem of adolescent girls. IOSR Journal Of Humanities And Social Science (IOSR-JHSS), 20(2), 42-46. https://doi.org/10.6084/M9.figshare.1353182

Tam, C. L., Lee, T. H., Har, W. M., \& Pook, W. L. (2011). Perceived social support and self-esteem towards gender roles: Contributing factors in adolescents. Asian Social Science, 7(8), 49-57. https://doi.org/10.5539/ass.v7n8p49

Tentama, F. (2014). Hubungan positive thinking dengan self acceptance pada difabel (bawaan lahir) di SLB Negeri 3 Yogyakarta. Jurnal Psikologi Positif Integratif, 2(2), 1-7. https://doi. org/10.14421/jpsi.2014.\%25x

Teoh, H. J. (2010). Self esteem amongst young adults: the effect of gender, social support and personality. Malaysian Journal of Psychiatry, 19(2), 1-9. Retrieved from https://www. mjpsychiatry.org/index.php/mjp/article/view/96

Triwahyuningsih, Y. (2017). Kajian meta-analisis hubungan antara self esteem dan kesejahteraan psikologis. Buletin Psikologi,25(1),26-35. https://doi.org/10.22146/buletinpsikologi.9382

Turner, R. J., Lloyd, D. A., \& Taylor, J. (2006). Physical disability and mental health: An epidemiology of psychiatric and substance disorders. Rehabilitation Psychology, 51(3), 214223. https://doi.org/10.1037/0090-5550.51.3.214

UU RI No. 8 Tahun 2016. (2016). Tentang penyandang disabilitas. http://www.dpr.go.id/dokjdih/ document/uu/1667.pd

Wagner, J., Becker, M., Lüdtke, O., \& Trautwein, U. (2015). The first partnership experience and personality development: a propensity score matching study in young adulthood. Social Psychological and Personality Science, 6(4), 455-463. https://doi. org/10.1177/1948550614566092

Wagner, J., Lüdtke, O., Robitzsch, A., Göllner, R., \& Trautwein, U. (2018). Self-esteem development in the school context: The roles of intrapersonal and interpersonal social predictors. Journal of Personality, 86(3), 481-497. https://doi.org/10.1111/jopy.12330

Yun, I., Jung, S., \& Yoo, J. (2015). Disability and violent victimization in a national sample of adolescents: A longitudinal study. Violence and Victims, 30(6), 1099-1116. https://doi. org/10.1891/0886-6708.VV-D-14-00008 